\title{
A Recombinant Multiepitope Protein for Hepatitis B Diagnosis
}

\author{
Marilen Queiroz de Souza, ${ }^{1}$ Alexsandro Sobreira Galdino, ${ }^{2}$ José Carlos dos Santos, ${ }^{1}$ \\ Marcus Vinicius Soares, ${ }^{1}$ Yanna C. de Nóbrega, ${ }^{3}$ Alice da Cunha Morales Álvares, \\ Sonia Maria de Freitas, ${ }^{4}$ Fernando Araripe Gonçalves Torres, ${ }^{1}$ \\ and Maria Sueli Soares Felipe ${ }^{1,5}$ \\ ${ }^{1}$ Laboratório de Biologia Molecular, Universidade de Brasília, 70910-900 Brasília, DF, Brazil \\ ${ }^{2}$ Laboratório de Biotecnologia de Microrganismos, Universidade Federal de São João Del-Rei, 35501-296 Divinópolis, MG, Brazil \\ ${ }^{3}$ Laboratório de Imunopatologia, Departamento de Patologia Molecular, Universidade de Brasília, 70910-900 Brasília, DF, Brazil \\ ${ }^{4}$ Laboratório de Biofísica, Instituto de Ciências Biológicas, Universidade de Brasília, 70910-900 Brasília, DF, Brazil \\ ${ }^{5}$ Pós-Graduação em Ciências Genômicas e Biotecnologia, Universidade Católica de Brasília, 70910-900 Brasília, DF, Brazil
}

Correspondence should be addressed to Maria Sueli Soares Felipe; msueliunb@gmail.com

Received 7 May 2013; Revised 30 August 2013; Accepted 9 September 2013

Academic Editor: Esteban Martinez

Copyright (C) 2013 Marilen Queiroz de Souza et al. This is an open access article distributed under the Creative Commons Attribution License, which permits unrestricted use, distribution, and reproduction in any medium, provided the original work is properly cited.

\begin{abstract}
Hepatitis B is a liver inflammation caused by hepatitis B virus (HBV) and can be diagnosed in clinical stage by hepatitis B core antibody from IgM class (anti-HBcIgM). Hepatitis B core antibody from IgG class (Anti-HBcIgG) appears quickly after IgM, reaching high titers in chronic hepatitis, and remains even after cure. Since hepatitis B core antibody (anti-HBc) is the first antibody identified and sometimes the only marker detected during the course of infection, it can be used both to indicate HBV acute infection (anti-HBc-IgM) and to identify individuals who have come into contact with the virus (anti-HBc-IgG). In this work we propose a recombinant hepatitis B core multiepitope antigen (rMEHB) to be used for diagnosis of hepatitis B. For this purpose, a synthetic gene coding for rMEHB was designed and cloned into vector pET21a with a 6xHis tag at the C-terminal. Time course induction in $E$. coli showed an induced protein with an apparent molecular mass of $\sim 21 \mathrm{kDa}$. Protein purification was performed by a single step with affinity chromatography Ni-NTA. Circular dichroism spectroscopy indicated rMEHB as a thermal stable protein at $\mathrm{pH} 7.0$ and 8.0. In these conditions rMEHB was successfully used to perform an enzyme linked immuno sorbent assay (ELISA) with positive and negative sera.
\end{abstract}

\section{Introduction}

Infections caused by hepatitis B virus (HBV) are a public health problem that concerns the entire world [1]. About a third of the world's population has already had contact with the virus during their lifetime. The World Health Organization (WHO) has estimated that there are more than 2 billion HBV infected individuals and about 378 million chronic carriers worldwide. Approximately 4.5 million new cases of $\mathrm{HBV}$ infection occur per year and a quarter progresses to liver disease [2]. HBV infection has a wide spectrum of liver diseases ranging from acute or fulminant hepatitis, chronic hepatitis, and cirrhosis to hepatocellular carcinoma (HCC) [3]. Infection occurs very often in early childhood when it is asymptomatic and often leads to the chronic carrier state [4].
In low endemic region like in the Central Asian republics, Southeast Asia, Subsaharan Africa, and the Amazon basin, the HBV carrier rate is over 8\% [2], whereas in low endemic regions like the United States, Northern Europe, Australia, and parts of South America, it is less than 2\% [2].

The HBV genome is a partially double-stranded DNA comprising about 3,200 nucleotides [5]. The genome is compact and contains sequences for four overlapping open reading frames (ORF) that encode structural and nonstructural proteins of the virus [6]. The first, ORF P, codes for a terminal protein on the minus strand as well as viral polymerase. ORF C codes for nucleocapsid structural protein as well as the hepatitis e antigen ( $\mathrm{HBeAg}$ ), which is responsible for immunomodulation and replication inhibition function. ORF S/pre-S codes for viral surface glycoproteins (HBsAg) 
TABLE 1: HBcAg epitopes selected to compose the recombinant protein.

\begin{tabular}{lcc}
\hline Epitope & Residues & References \\
\hline (1) CWGELMNLATWVGSNLEDPASRE & $61-83$ & Sallberg et al., 1994 [27]; Salfeld et al., 1989 [8] and Thermet et al., 2004 [28]. \\
(2) CLTFGRETVLEY & $107-118$ & Collucci et al., 1988 [29]. \\
(3) TPPAYR & $128-133$ & Sallberg et al., 1991 [30]. \\
(4) PPNAPILSTLPE & $134-145$ & Takahashi et al., 2001 [31]. \\
\hline
\end{tabular}

that bind to cell receptors and facilitate viral entry [7]. HBV has a polyhedral structure composed of identical subunits of $21 \mathrm{kDa}$ and it is serologically defined as HBcAg which has been proposed to be related to $\mathrm{HBeAg}$, a second HBVinduced antigen based on the fact that $\mathrm{HBcAg}$ can be converted into $\mathrm{HBeAg}$ after proteolysis [8].

The virus interferes with the function of the liver while replicating in hepatocytes. As a result of pathological damage, the liver becomes inflamed [4]. Currently, four major serotypes and nine minor subtypes have been serologically identified [3]. The complete DNA sequencing of HBV isolates worldwide have led to the identification of eight genotypes (A to $\mathrm{H}$ ) and a number of subgenotypes, showing different ethno/geographic distribution [3,9]. Genotype A has been reported in Northern Europe, North and South Americas, India, and Central Africa, while isolates belonging to genotypes B and C have been observed in Southeast Asia and the Far East. Genotype D has a worldwide distribution and predominates in the Mediterranean and Middle East regions. Genotype $\mathrm{E}$ and $\mathrm{F}$ are prevalent in West Africa and in Amerindian populations, respectively. Genotype $G$ has been identified in Europe, Mexico, and the USA, and genotype $\mathrm{H}$ has been found in Central America [10-12]. In Brazil, all genotypes can be found being genotypes A the most prevalent [13]. Despite a safe and effective vaccine is being available for more than two decades, HBV infection is still regarded as a global health problem [3].

The diagnosis of an infection by HBV can be carried out by molecular tests (quantitative and qualitative search of HBV DNA) and by serological tests. In this case, HBsAg and $\mathrm{HBeAg}$, and anti-HBsAg, anti-HBeAg, and anti-HBcAg antibodies are identified in the serum during infection [14]. These antigens and antibodies appear and disappear in the serum according to the evolutionary phase of the illness [15]. During the incubation period, a few days after the appearance of antigen $\mathrm{HBsAg}$, anti-HBc antibodies are detected [16]. In the initial phase, the IgM class of antibodies (anti-HBc-IgM) is predominated, remaining up to three months after the beginning of the clinical signs. During infection, anti-HBc from the IgG class (anti-HBc-IgG) presents ever-growing titers and remains detectable during its lifetime [2]. Therefore, while anti-HBc-IgM represents an important contribution to the diagnosis during the acute phase of the infection, anti$\mathrm{HBc}$-IgG is an important clinical and epidemiological marker for this infection. Patients that remain positive for many years towards anti-HBc markers run the risk of transmitting the illness on rare occasions (when donating organs or tissues) or reactivating infection by $\mathrm{HBV}$ when immunosuppressed [7]. During routine clinical practice, total anti-HBc serological tests are used in order to detect IgM and IgG antibodies [2]. Although the HBsAg is the most abundant protein used as diagnostic marker of hepatitis B infection [17], the test for anti-HBs can be ambiguous either by referring to the patients who came in contact with the HBV, or simply patients vaccinated but never came in contact with HBV. Furthermore, HBsAg is very heterogeneous [17] and a diagnostic test using multieptope protein from HBsAg would have to consider all immunodominant epitopes, which would thus result in a very large protein. On the other hand, because the coding region for HBcAgis conserved in the different HBV genotypes [15], the use of this region for diagnostic purposes could be more reliable.

There is a great need to develop highly efficient and inexpensive diagnostic methods, which should also be sensitive and specific. The development of recombinant proteins containing a high density of conserved epitopes has been a rational strategy for antibody recognition in diagnostic [1824]. Multiepitope proteins have shown a great capacity to expose a wide range of epitopes with great efficiency, thus permitting the increase of the sensitivity of the test [1824]. Several studies have been published on multiepitopes proteins for use successfully in diagnostic [18-24]. However, to date, no studies on the use of multiepitope proteins for hepatitis B diagnosis have been published. This prompted us to develop a recombinant multiepitope antigenic protein from the nucleocapsid of $\mathrm{HBV}$ ( $\mathrm{HBcAg}$ ) that could be useful for hepatitis B diagnosis.

\section{Material and Methods}

2.1. Design and Cloning of the Synthetic Gene. The gene coding for the recombinant hepatitis B multiepitope protein (rMEHB) was designed after selecting four conserved epitopes from the HBV virus (Table 1) and taking into account the $E$. coli codon usage. A609 pbNdeI/XhoI fragment was custom synthesized (Epoch Biosciences) and cloned into pET21a resulting in plasmid pET (rMEHB). The synthetic gene contained 3 copies of a stretch of the following epitope: epitopes 1 and 2 were separated by glycine and serine (GSGSG) flexible linkers, and epitopes 3 and 4 were present in tandem. The gene also contained six histidine residues (His-tag) at the C-terminal to allow protein detection and purification. The rMEHB consists of epitope 1 (CWGELMNLATWVGSNLEDPASRE) epitope 2 (CLTFGRETVLEY) and fused epitopes 3 and 4 (TPPAYRPPNAPILSTLPE). All epitopes were separated by the refereed flexible link. The structure showed above was repeated for three times originating a $21 \mathrm{kDa}$ recombinant protein. 
2.2. Expression and Purification of rMHEB. E. coli BL21 ( $\lambda$ DE3) pLysS cells were transformed with the pET (rMEHB) and a single colony was inoculated in Luria-Bertani (LB) medium and incubated at $37^{\circ} \mathrm{C}$ with shaking overnight. The culture was grown until optical density $\left(\mathrm{OD}_{600 \mathrm{~nm}}\right)$ until 0.6 when $1 \mathrm{mM}$ of IPTG was added. Bacteria from induced culture were centrifuged at $6000 \times \mathrm{g}$ for $30 \mathrm{~min}$ at $4^{\circ} \mathrm{C}$ and the resulting pellet was stored at $-80^{\circ} \mathrm{C}$. The purification strategy involved addition of lysis buffer $(8 \mathrm{M}$ urea, $50 \mathrm{mM}$ $\mathrm{NaH}_{2} \mathrm{PO}_{4}, 300 \mathrm{mM} \mathrm{NaCl}, 10 \mathrm{mM}$ imidazole, and $\mathrm{pH}$ 8.0) to the pellet following incubation at $4^{\circ} \mathrm{C}$ overnight. The system was then sonicated and $500 \mu \mathrm{L} \mathrm{Ni-NTA}$ resin (Amersham Bioscience) was added to the supernatant for batch purification. For purification the resin was washed ( $8 \mathrm{M}$ urea, $50 \mathrm{mM}$ $\mathrm{NaH}_{2} \mathrm{PO}_{4}, 300 \mathrm{mM} \mathrm{NaCl}, 20 \mathrm{mM}$ imidazole, and $\mathrm{pH}$ 8.0) and proteins eluted with $8 \mathrm{M}$ urea, $50 \mathrm{mM} \mathrm{NaH} \mathrm{PO}_{4}, 300 \mathrm{mM}$ $\mathrm{NaCl}$, and $500 \mathrm{mM}$ imidazole ( $\mathrm{pH} 8.0$ ).

2.3. Electrophoresis and Western Blotting. Protein samples were separated on 12\% SDS-PAGE and electroblotted onto polyvinylidenefluoride (PVDF) membrane. The membrane was blocked with 5\% milk in PBST (7 mM Na $2 \mathrm{HPO}_{4}, 137 \mathrm{mM}$ $\mathrm{NaCl}, \mathrm{pH} 7.4$, and $1 \%$ Tween 20 ) for $2 \mathrm{~h}$ at room temperature. After 3 washes with PBS, the membrane was then incubated for $2 \mathrm{~h}$ at room temperature with monoclonal mouse antipoliHis AP (Alkaline Phosphatase, Sigma), diluted 1:1000 in PBS. After three washes with PBST the specific protein band was visualized by the nitroblue tetrazolium/5bromo-4chloro- $3^{\prime}$-indolylphosphate (NBT/BCIP) detection method.

2.4. Circular Dichroism Spectroscopy. Circular dichroism (CD) assays were carried out using Jasco J-815 spectropolarimeter (Jasco, Tokyo, Japan) equipped with a Peltier-type temperature controller. Far-UV spectra (260 to $195 \mathrm{~nm}$ ) of rMEHB (0.08 $\left.\mathrm{mg} \cdot \mathrm{mL}^{-1}\right)$ were analyzed in $2 \mathrm{mM}$ MOPS buffer $\mathrm{pH} 7.0$ and 8.0 at $25^{\circ} \mathrm{C}$ using $0.2 \mathrm{~cm}$ path length quartz cuvette. Four consecutive measurements were accumulated and the mean spectra were recorded. The observed ellipticities were converted into molar ellipticity $([\theta])$ based on molecular mass per residue of $115 \mathrm{Da}$. Thermal denaturation assays of rMEHB were performed, raising the temperature from $25^{\circ} \mathrm{C}$ to $95^{\circ} \mathrm{C}$, and monitored by dichroic signal at $200 \mathrm{~nm}$. The temperature and $\mathrm{pH}$ dependence on secondary structure content were estimated from farUV CD curve adjustments, using the network secondary structure estimator from concentration-independent method (http://perry.freeshell.org/raussens.html) [25]. In order to support the secondary structure prediction, the rMEHB amino acid sequence was submitted to network protein sequence analysis program [26].

2.5. Activity Test of $r M E H B$. The immune enzymatic assay was used to detect specific binding of the recombinant protein rMEHB to anti-HBc. A commercial HBV diagnostic kit (ETIEBK PLUS No 140-Diasorin) was used. In this kit, the provided antigen was replaced by $\mathrm{MEHB}$, and a monoclonal anti-HBc was used. For each well different concentration

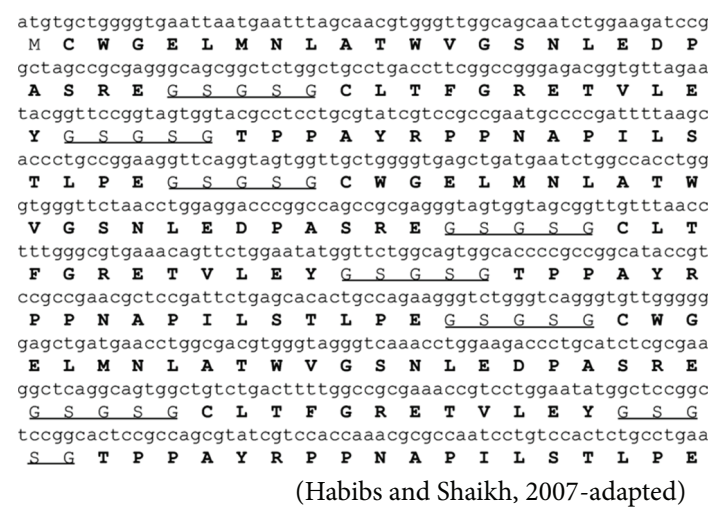

FIGURE 1: Nucleotide and predicted amino acid sequences of rMEHB.

$50 \mathrm{ng}, 500 \mathrm{ng}, 1 \mu \mathrm{g}, 10 \mu \mathrm{g}$, and $15 \mu \mathrm{g}$ of $\mathrm{rMEHB}$ were added in triplicate. After incubation at $37^{\circ} \mathrm{C}$ for $2 \mathrm{~h}$, the wells were washed with PBST. Then, $100 \mu \mathrm{L}$ of secondary antibody (monoclonal mouse anti-poliHis AP-Sigma) were added. After incubation at $37^{\circ} \mathrm{C}$ for $2 \mathrm{~h}$, the plate surface was again washed with PBST. After this procedure, $p$-nitrophenyl phosphate (pNPP) was added as substrate for alkaline phosphatase following detection at $405 \mathrm{~nm}$. The commercial kit was based on a competitive test in which the antibody present on the plate surface competes with the antibody present in serum of patients infected by the antigen. For this, the positive and negative sera of the commercial kit were used as controls.

\section{Results and Discussion}

3.1. Design of the Hepatitis B Multiepitope Protein ( $r M E H B)$. The use of multiple native or recombinant proteins in diagnosis has an important impact on the price of immune-trial kits. Alternatively, the use of multiepitope proteins produced in $E$. coli and purified by a single step procedure allows the design of less expensive kits which can be used routinely in laboratory tests [18]. In addition, the rationally designed recombinant proteins presenting high epitope density may provide increased sensitivity and specificity [18-24].

The multiepitope protein developed in this work consists of a single polypeptide chain containing conserved epitopes which are prevalent worldwide, particularly in Brazil. These epitopes correspond to viral regions that are known to be capable of efficiently recognizing specific $\mathrm{HBc}$ antibodies in infected individuals. The epitopes used to design the antigenic protein are derived from structural core regions and were selected based on four criteria: (i) immunodominance, (ii) specificity towards anti-HBc antibodies, (iii) sequential construction of the epitopes separated by specific linker, and (iv) phylogenetic conservation of the majority of the HBV genotypes. Four epitopes from the core region were selected for rMEHB (Table 1) and were separated by glycine and serine flexible linkers. In order to increase epitope density the four epitope cluster was repeated three times resulting in a peptide of $\sim 21 \mathrm{kDa}$ which was called rMEHBV (Figure 1). 


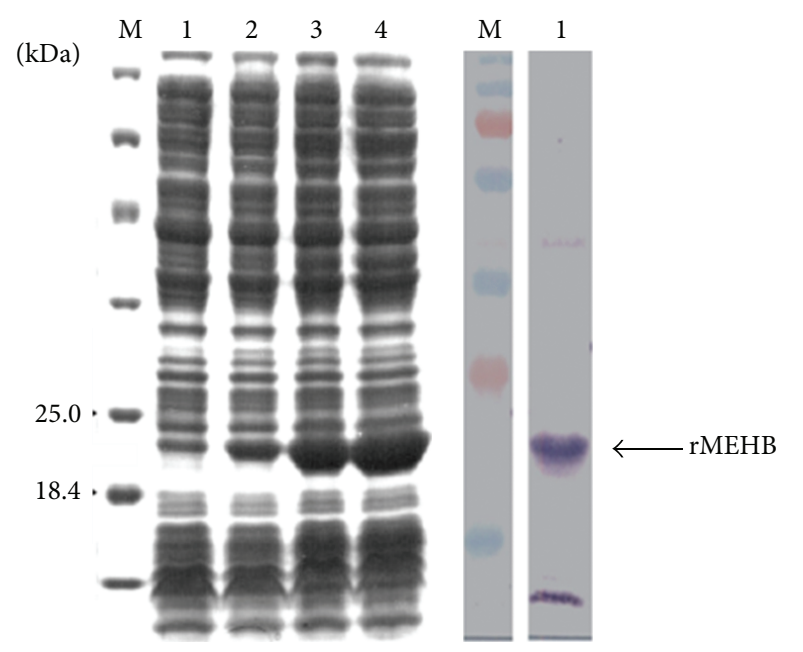

(a)

(b)
Figure 2: Time course rMEHB expression in E. coli BL21 ( $\lambda \mathrm{DE} 3$ ) and analysis by SDS-PAGE12\%. (a) Lane M, unstained protein molecular mass marker (Fermentas Life Sciences); Lane 1, uninduced control; Lanes 2-4, after $0.5,1.5$, and 2.5 hours of induction, respectively. (b) Western blotting analysis of the purified rMEHB. The monoclonal antibody, antipolyhistidine conjugated alkaline phosphatase, was diluted 1:1000 in PBS.

3.2. Expression and Purification of $r M E H B$. The use of recombinant multiepitope proteins over expressed in E. coli can be used in diagnostic kits for hepatitis B with several advantages: lower costs, facilitated manipulation, and elimination of problems concerning concentration of different peptides in the kits [18-24].

As shown in Figure 2(a), induction of protein expression in E. coli resulted in the appearance of a $\sim 21 \mathrm{kDa}$ species (consisted with the expected size of rMEHV) which was confirmed by Western blotting to have a his tag (Figure 2(b)). The expressed rMEHB formed inclusion bodies that were disrupt and solubilized by using $6 \mathrm{M}$ urea. Fractions collected during different steps of the purification were analyzed by SDS-PAGE (Figure 3). Three steps of washing remove most protein contaminants. Elution of the bound proteins using $500 \mathrm{mM}$ imidazole resulted in highly purified rMEHB rendering $1.5 \mathrm{mg}$ from $25 \mathrm{~mL}$ of soluble protein obtained after cells lysis (Figure 3, lanes 6-9).

3.3. Circular Dichroism Spectroscopy Analysis. Circular dichroism is a useful spectroscopic tool to predict secondary structures of proteins and to correlate conformation properties of proteins dependent on environmental conditions [32, 33]. This technique was performed with the purpose of investigating the structural stability and secondary structure arrangement of the recombinant protein $\mathrm{rMEHB}$ at different $\mathrm{pHs}$ and temperatures. $\mathrm{CD}$ spectra of rMEHB at pH 7.0 and $\mathrm{pH} 8.025^{\circ} \mathrm{C}$ were similar to each other and displayed a negative band at $200 \mathrm{~nm}$, typically being an unordered structure pattern (Figure 4). The secondary structure content of rMEHB estimated from spectra according to the Raussens et al. method [25] shows

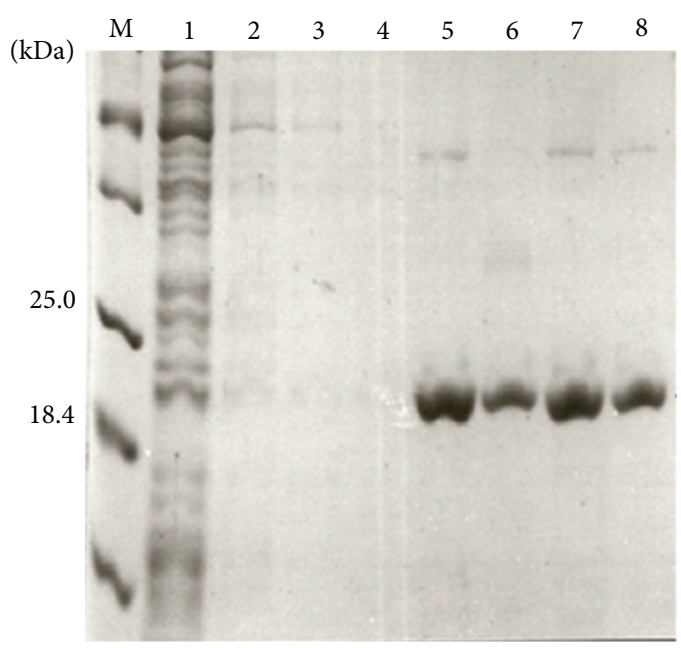

FIGURE 3: Analysis of rMEHBby SDS-PAGE 12\% after purification procedure. Fractions were collected after Ni-NTA chromatography. Lane M, molecular mass markers (Weight Standard, Broad Range, BioRad). Lane 1, flow-through; Lanes 2-4, wash steps; Lanes 5-8 purified rMEHB after elution with $500 \mathrm{mM}$ imidazole.

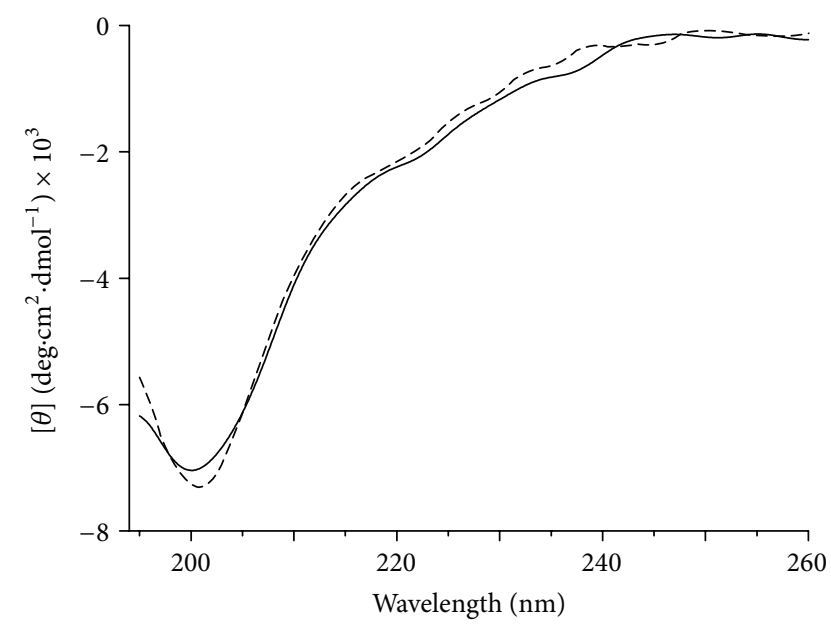

FIGURE 4: Far-UV CD spectra of rMEHB $\left(0.08 \mathrm{mg} \cdot \mathrm{mL}^{-1}\right)$ in $2 \mathrm{mM}$ MOPS buffer at $25^{\circ} \mathrm{C}$. Solid and dashed lines indicate the CD spectra of MEHB at $\mathrm{pH} 7.0$ and 8.0, respectively.

predominance of unordered and $\beta$-sheet structures in both $\mathrm{pH} 7.0$ and 8.0 at $25^{\circ} \mathrm{C}$ (Table 2). These results are consistent with those obtained according to secondary structure prediction by network protein sequence analysis program in which $43.9 \% \beta$-strand and $44.4 \%$ unordered structure were predicted.

Thermal stability of recombinant protein at $\mathrm{pH} 7.0$ and 8.0 was monitored by gradual decrease of the dichroic signal at $200 \mathrm{~nm}$ (Figures 5(a) and 5(b)). As shown in Figure 5(c), no pattern of protein denaturation could be verified, as evidenced by no significant changes in the molar ellipticity as a function of the temperature. However, the dichroic signal at $200 \mathrm{~nm}$ decreasing from about $-7,300$ to $-6,300$ degree $\cdot \mathrm{cm}^{2} \cdot \mathrm{dmol}^{-1}$ (Figure 5(c)) indicates that the 


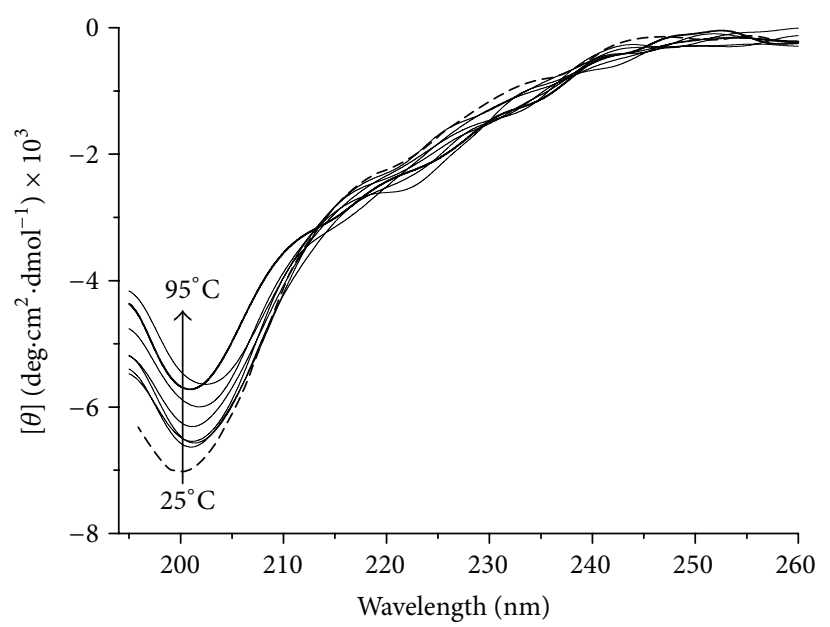

(a)

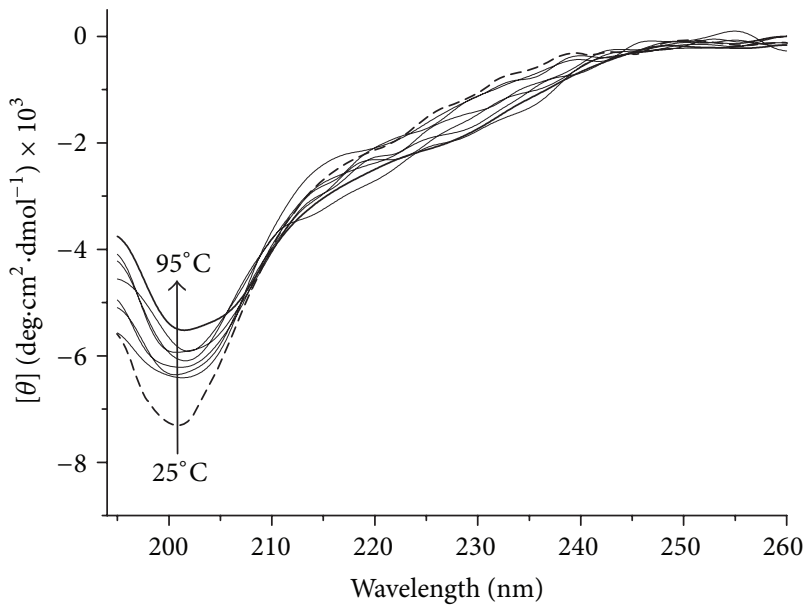

(b)

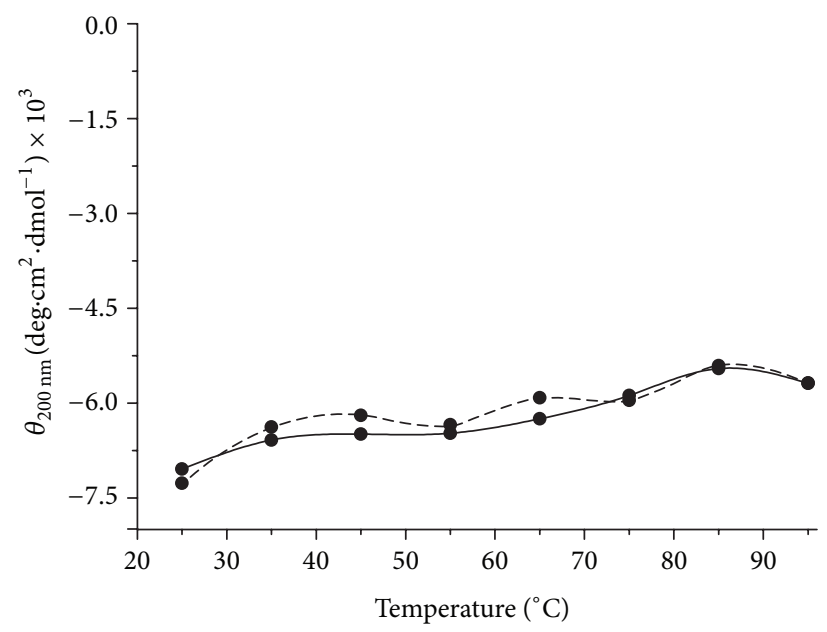

(c)

FIGURE 5: Heat-induced unfolding of rMEHB by circular dichroism (CD). (a) Far UV CD spectra in 2 mM MOPS buffer pH 7.0 and (b) pH 8.0, as a function of temperature. Molar ellipticities [ $\theta$ ] were measured from 260 to $195 \mathrm{~nm}$ at temperature rising from $25^{\circ} \mathrm{C}$ to $95^{\circ} \mathrm{C}$. The arrows indicate decreased dichroic signal at $200 \mathrm{~nm}$ with increased temperature. (c) Temperature induced unfolding curves of rMEHB in $2 \mathrm{mM}$ MOPS buffer $\mathrm{pH} 7.0(---)$ and $\mathrm{pH} 8.0(-)$ monitored at $200 \mathrm{~nm}$.

TABLE 2: Secondary structure content of rMEHB calculated from far-UV (260-195 nm) CD curves adjustments in $2 \mathrm{mM}$ MOPS $\mathrm{pH} 7.0$ and 8.0 using the network secondary structure estimator from concentration independent Raussens et al. method (http://perry.freeshell.org/raussens.html) [25].

\begin{tabular}{lcccc}
\hline \multirow{2}{*}{ Secondary structure (\%) } & \multicolumn{2}{c}{$\mathrm{pH} 7.0$} & \multicolumn{2}{c}{$\mathrm{pH} 8.0$} \\
& $25^{\circ} \mathrm{C}$ & $95^{\circ} \mathrm{C}$ & $25^{\circ} \mathrm{C}$ & $95^{\circ} \mathrm{C}$ \\
\hline$\alpha$-helix & 7.5 & 5.3 & 8.0 & 7.4 \\
$\beta$-sheet & 32.7 & 36.7 & 33.1 & 33.1 \\
$\beta$-turn & 12.5 & 14.5 & 12.5 & 12.9 \\
Random-coil & 40.9 & 40.5 & 40.8 & 40.9
\end{tabular}

secondary structure alteration throughout the temperature range of 25 to $95^{\circ} \mathrm{C}$ is compatible with low conformational changes in the protein. These results indicate that $\mathrm{rMEHB}$ is a thermal stable protein at $\mathrm{pH} 7.0$ and 8.0 upon raising the temperature from $25^{\circ} \mathrm{C}$ to $95^{\circ} \mathrm{C}$, since no denaturing process was observed in these conditions.

The high stability of protein at both pHs can be justified, in part, by the amino acid composition. Overall, the most abundant amino acid residues composing the rMEHB are serine plus threonine (19.5\%) and glycine plus proline $(26.3 \%)$. These amino acids provide a high content of hydrogen bonding (hydrogen bond-forming residues) and polypeptide folded in globular protein (turn and loop forming residues), respectively, favoring a more compact state resulting in the stabilization of the protein even at $95^{\circ} \mathrm{C}$. Furthermore, it can be also justified by the instability index (II) of 36.14 , a physical-chemical parameter used for characterization of protein stability [25], predicted for amino acids sequence (http://web.expasy.org/protparam/) that classifies rMEHB as a stable protein. 


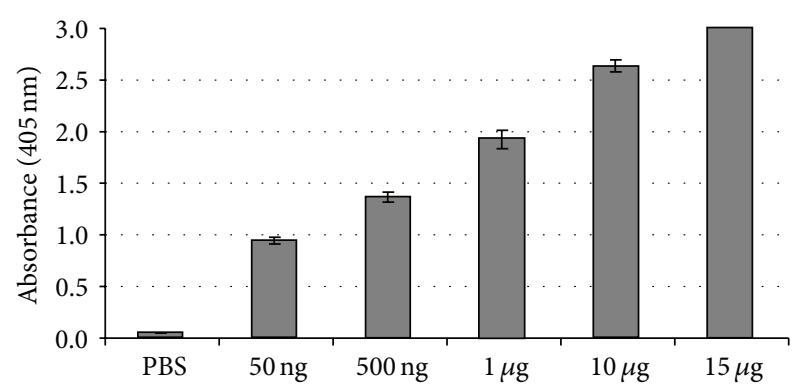

Figure 6: Enzyme linked immuno sorbent assay (ELISA) using rMEHB and monoclonal antibody Anti-HB, present on the plate surface of a commercial kit for hepatitis B diagnosis. Several concentrations of rMEHB were used as following: $50 \mathrm{ng}, 500 \mathrm{ng}, 1 \mu \mathrm{g}$, $10 \mu \mathrm{g}$, and $15 \mu \mathrm{g}$. PBS was used as negative control. Antipolyhistidine conjugated alkaline phosphatase was the second antibody and the substrate was pNPP.

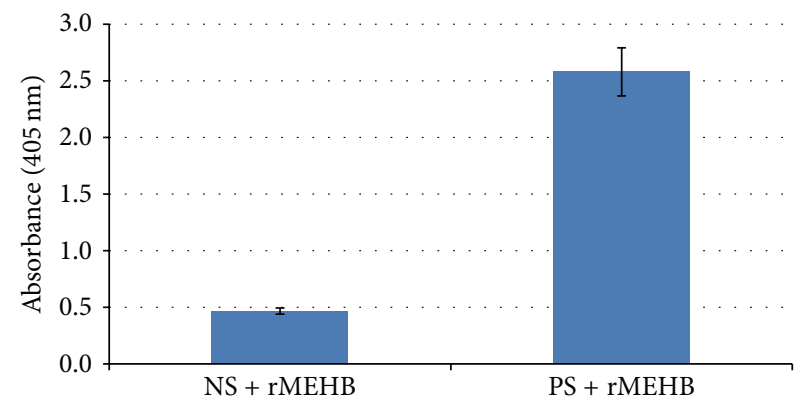

FIGURE 7: Immunological assay of rMEHB. The commercial antigen was replaced by rMEHB for the competitive test. NS: commercial negative control serum. PS: commercial positive control serum. Antipolyhistidine conjugated alkaline phosphatase was the second antibody and the substrate was pNPP.

Analysis of these structural parameters is very important, considering that $\mathrm{rMEHB}$, a recombinant multiepitope protein, was expressed in order to preserve its tridimensional structure and the exposed regions containing defined epitopes for diagnostic purposes. Additionally, the stability of rMEHB is of fundamental importance in order to facilitate its transport for hepatitis B diagnosis. Finally, besides the high thermal stability, the results revealed the similar folding pattern of rMEHB under neutral and alkaline conditions and confirmed that recombinant protein can be used under these conditions for hepatitis B diagnosis.

3.4. Activity Test of $r M E H B$. In order to compare antigenic activity of the recombinant protein, a commercial diagnostic kit containing a monoclonal anti-HBc capable of recognizing anti-HBc was used. Figure 6 shows that rMEHB in different concentrations was recognizes by anti-HBc antibodies. Also, the ability of rMEHB to be used as a diagnostic test for hepatitis $\mathrm{B}$ was confirmed by immune assay, replacing a commercial antigen by rMEHB (Figure 7). The recombinant antigen $\mathrm{HBcAg}$ binds to the anti-HBc antibodies coated on the board or binds to antibodies present in the sample. For this test, the commercial antigen was also used as a control (data not shown), and it was observed that the recombinant antigen rMEHB responds as well as the commercial antigen.

\section{Conclusions}

The rMEHB could be used as input for hepatitis B diagnosis ensuring the use of healthy blood. The high density and the solvent-exposed of the conserved epitopes in the recombinant protein could contribute to a high degree of specificity and sensitivity, although not yet determined. The CD data showed that $\mathrm{rMEHB}$ is a stable protein mainly folded as unordered and $\beta$-strand structures. This structural feature probably favors the epitopes exposure and consequently the epitope-antibody recognition and binding processes. Furthermore, the high level of expression of rMEHB in E. coli and its single-step affinity purification make this approach an inexpensive process to obtain this protein.

\section{Authors' Contribution}

Marilen Queiroz de Souza and Alexsandro Sobreira Galdino contributed equally to this work.

\section{Conflit of Interests}

None of the authors has any other conflict of interests related to this paper.

\section{Acknowledgments}

M. Souza was supported by a master's scholarship from CAPES/Brazil. The authors declare no conflict of interests related to this study. This work was supported by grants from FINEP, CNPq, FAPDF, FAPEMIG, and CAPES.

\section{References}

[1] WHO, "Prevention \& Controlo of Viral Hepatitis Infection: Framework for Global Action," 2012, http://www.who.int/csr/ disease/hepatitis/GHP_framework.pdf.

[2] E. Franco, B. Bagnato, M. G. Marino, C. Meleleo, L. Serino, and L. Zaratti, "Hepatitis B: epidemiology and prevention in developing countries," World Journal of Hepatology, vol. 4, pp. 74-80, 2012.

[3] Y.-H. Shi, "Correlation between hepatitis B virus genotypes and clinical outcomes," Japan Journal Infection Diseases, vol. 65, pp. 476-482, 2012.

[4] WHO, "Global Alert and Response (GAR): Hepatitis B," http://www.who.int/csr/disease/hepatitis/whocdscsrlyo20022/ en/index3.html.

[5] L. Stuyver, S. De Gendt, C. Van Geyt et al., "A new genotype of hepatitis B virus: complete genome and phylogenetic relatedness," Journal of General Virology, vol. 81, no. 1, pp. 67-74, 2000.

[6] W. Offensperger, S. Wahl, A. R. Neurath et al., "Expression in Escherichia coli a cloned DNA sequence encoding the pre-S2 region of hepatitis B virus," Proceedings of the National Academy of Sciences of the United States of America, vol. 82, no. 22, pp. 7540-7544, 1985. 
[7] B. S. S. Guirgis, R. O. Abbas, and H. M. E. Azzazy, "Hepatitis B virus genotyping: current methods and clinical implications," International Journal of Infectious Diseases, vol. 14, no. 11, pp. e941-e953, 2010.

[8] J. Salfeld, E. Pfaff, M. Noah, and H. Schaller, "Antigenic determinants and functional domains in core antigens and $\mathrm{e}$ antigen from hepatitis B virus," Journal of Virology, vol. 63, no. 2, pp. 798-808, 1989.

[9] R. C. Ferreira, F. P. Rodrigues, S. A. Teles et al., "Prevalence of hepatitis B virus and risk factors in Brazilian non-injecting drug users," Journal of Medical Virology, vol. 81, no. 4, pp. 602-609, 2009.

[10] H. Norder, A.-M. Couroucé, P. Coursaget et al., "Genetic diversity of hepatitis B virus strains derived worldwide: genotypes, subgenotypes, and HBsAg subtypes," Intervirology, vol. 47, no. 6, pp. 289-309, 2004.

[11] F. B. Hollinger, "Hepatitis B virus genetic diversity and its impact on diagnostic assays," Journal of Viral Hepatitis, vol. 14, no. 1, pp. 11-15, 2007.

[12] S. Schaefer, "Hepatitis B virus taxonomy and hepatitis B virus genotypes," World Journal of Gastroenterology, vol. 13, no. 1, pp. 14-21, 2007.

[13] M. V. Alvarado-Mota and J. R. Pinho, "Epidemiological update of hepatitis B, C and delta in Latin America," Antiviral Therapy, vol. 18, pp. 429-433, 2013.

[14] C. N. Shiratori, F. E. Hirai, and E. H. Sato, "Characteristics of corneal donors in the Cascavel Eye Bank: impact of the anti$\mathrm{HBc}$ test for hepatitis B," Arquivos Brasileiros de Oftalmologia, vol. 74, no. 1, pp. 17-20, 2011.

[15] R. Focaccia, Tratado de Hepatites Virais, Editora Atheneu, 2003.

[16] L. C. Silva and C. F. H. Granato, Importância Clínica dos Marcadores Virais, Savier Editora de livros médicos LTDA, 2nd edition, 1995.

[17] J. Lei, B. A. Campbell, C. Cervantes, L. Bronstein, D. Hong, and D. Sustarsic, "Detection of Hepatitis B virus surface antigen (HBsAg) mutants by immulite $2000 \mathrm{HBsAg}$ assay," DPC Technical Report ZB248-A, 2006.

[18] M. S. Duthie, M. N. Hay, C. Z. Morales et al., "Rational design and evaluation of a multiepitope chimeric fusion protein with the potential for leprosy diagnosis," Clinical and Vaccine Immunology, vol. 17, no. 2, pp. 298-303, 2010.

[19] C. Camussone, V. Gonzalez, M. S. Belluzo et al., "Comparison of recombinant Trypanosoma cruzi peptide mixtures versus multiepitope chimeric proteins as sensitizing antigens for immunodiagnosis," Clinical and Vaccine Immunology, vol. 16, no. 6, pp. 899-905, 2009.

[20] Z. Cheng, J.-W. Zhao, Z.-Q. Sun et al., "Evaluation of a novel fusion protein antigen for rapid serodiagnosis of tuberculosis," Journal of Clinical Laboratory Analysis, vol. 25, no. 5, pp. 344349, 2011.

[21] J. Dai, M. Jiang, Y. Wang, L. Qu, R. Gong, and J. Si, "Evaluation of a recombinant multiepitope peptide for serodiagnosis of Toxoplasma gondii infection," Clinical and Vaccine Immunology, vol. 19, no. 3, pp. 338-342, 2012.

[22] N. K. Tripathi, A. Shrivastva, P. Pattnaik et al., "Production, purification and characterization of recombinant dengue multiepitope protein," Biotechnology and Applied Biochemistry, vol. 46, no. 2, pp. 105-113, 2007.

[23] X. Lin, Y. Chen, and J. Yan, "Recombinant multiepitope protein for diagnosis of leptospirosis," Clinical and Vaccine Immunology, vol. 15, no. 11, pp. 1711-1714, 2008.
[24] C. A. Dipti, S. K. Jain, and K. Navin, "A novel recombinant multiepitope protein as a hepatitis $\mathrm{C}$ diagnostic intermediate of high sensitivity and specificity," Protein Expression and Purification, vol. 47, no. 1, pp. 319-328, 2006.

[25] V. Raussens, J.-M. Ruysschaert, and E. Goormaghtigh, "Protein concentration is not an absolute prerequisite for the determination of secondary structure from circular dichroism spectra: a new scaling method," Analytical Biochemistry, vol. 319, no. 1, pp. 114-121, 2003.

[26] C. Combet, C. Blanchet, C. Geourjon, and G. Deléage, "NPS@: network protein sequence analysis," Trends in Biochemical Sciences, vol. 25, no. 3, pp. 147-150, 2000.

[27] M. Sällberg, U. Rudén, B. Wahren, and L. O. Magnius, "Immune recognition of linear antigenic regions within the hepatitis $\mathrm{B}$ pre- $\mathrm{C}$ and $\mathrm{C}$-gene translation products using synthetic peptides," Journal of Medical Virology, vol. 42, no. 1, pp. 7-15, 1994.

[28] A. Thermet, M. Robaczewska, C. Rollier et al., "Identification of antigenic regions of duck hepatitis $\mathrm{B}$ virus core protein with antibodies elicited by DNA immunization and chronic infection," Journal of Virology, vol. 78, no. 4, pp. 1945-1953, 2004.

[29] G. Colucci, Y. Beazer, C. Cantaluppi, and C. Tackney, "Identification of a major hepatitis B core antigen ( $\mathrm{HBcAg})$ determinant by using synthetic peptides and monoclonal antibodies," Journal of Immunology, vol. 141, no. 12, pp. 4376-4380, 1988.

[30] M. Sällberg, U. Rudén, B. Wahren, M. Noah, and L. O. Magnius, "Human and murine B-cells recognize the $\mathrm{HBeAg} / \mathrm{beta}$ (or HBe2) epitope as a linear determinant," Molecular Immunology, vol. 28, no. 7, pp. 719-726, 1991.

[31] K. Takahashi, S. Mishiro, and A. M. Prince, "Novel hepatitis $B$ virus strain from a chimpanzee of Central Africa (Pan troglodytes troglodytes) with an unusual antigenicity of the core protein," Intervirology, vol. 44, no. 5, pp. 321-326, 2001.

[32] W. C. Johnson Jr., "Circular dichroism and its empirical application to biopolymers," Methods of Biochemical Analysis, vol. 31, pp. 61-163, 1985.

[33] R. W. Woody, "Theory of circular dichroism of proteins," in Circular Dichroism and the Conformational Analysis of Biomolecules, G. D. Fasman, Ed., pp. 25-30, Plenum Press, New York, NY, USA, 1996. 

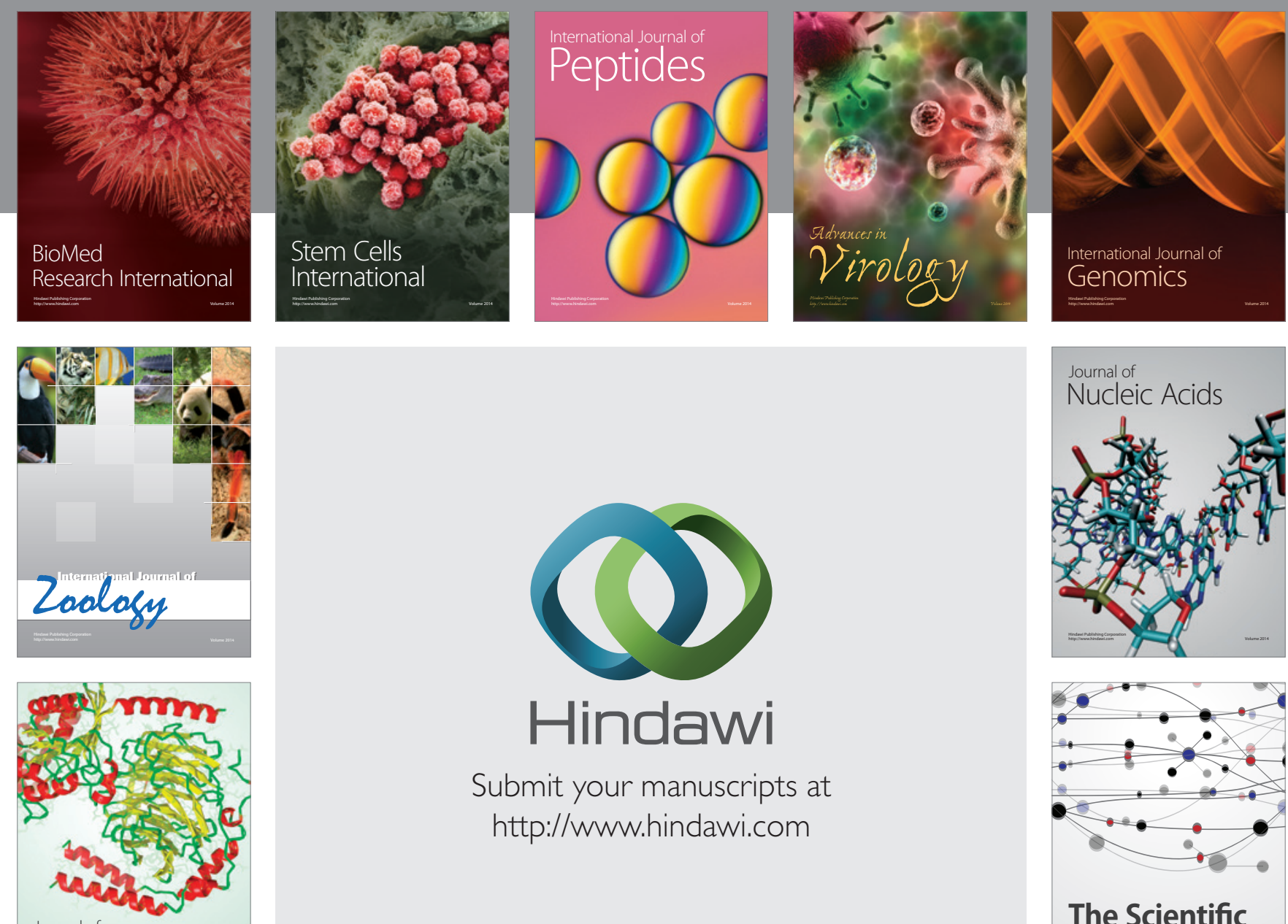

Submit your manuscripts at

http://www.hindawi.com

Journal of
Signal Transduction
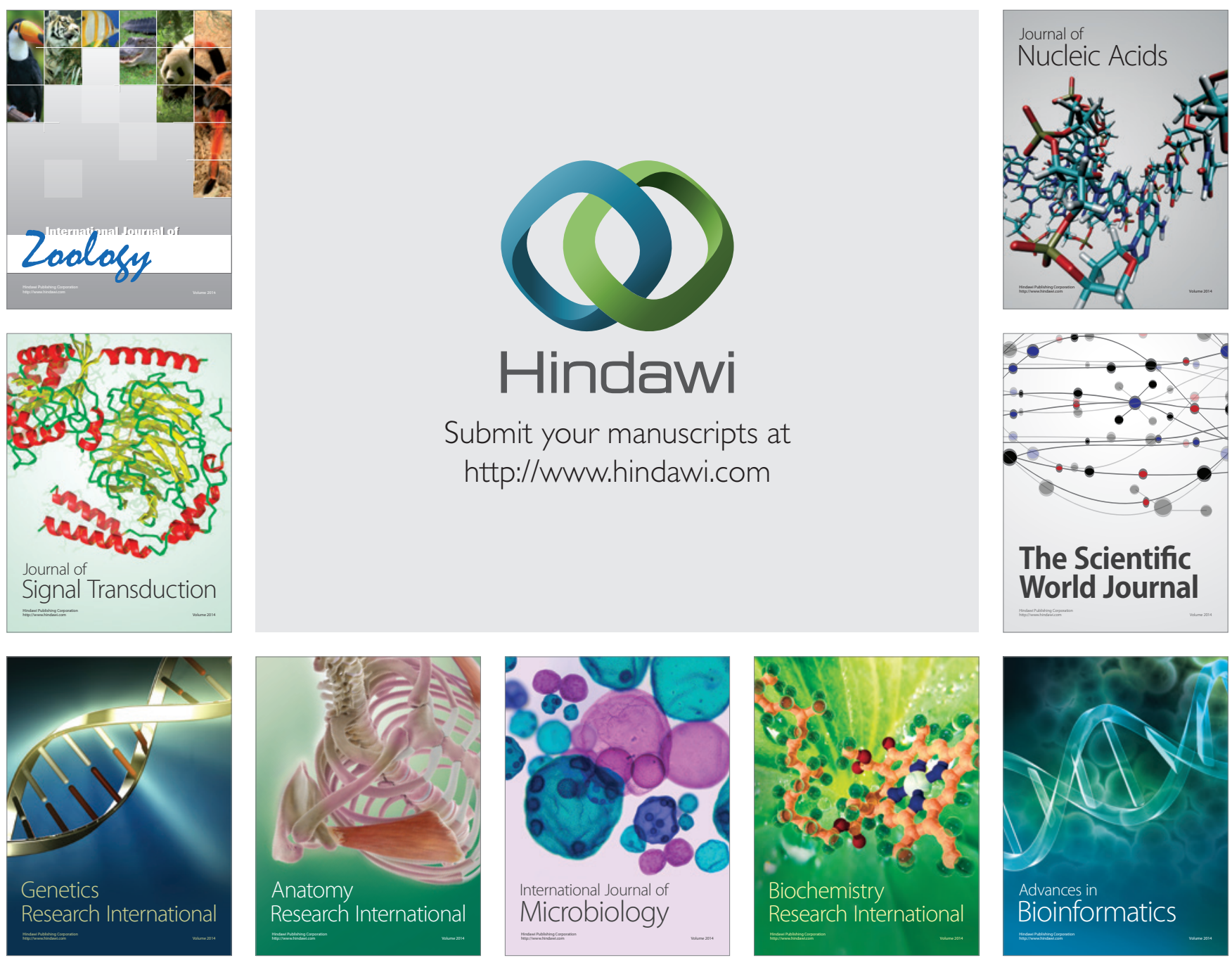

The Scientific World Journal
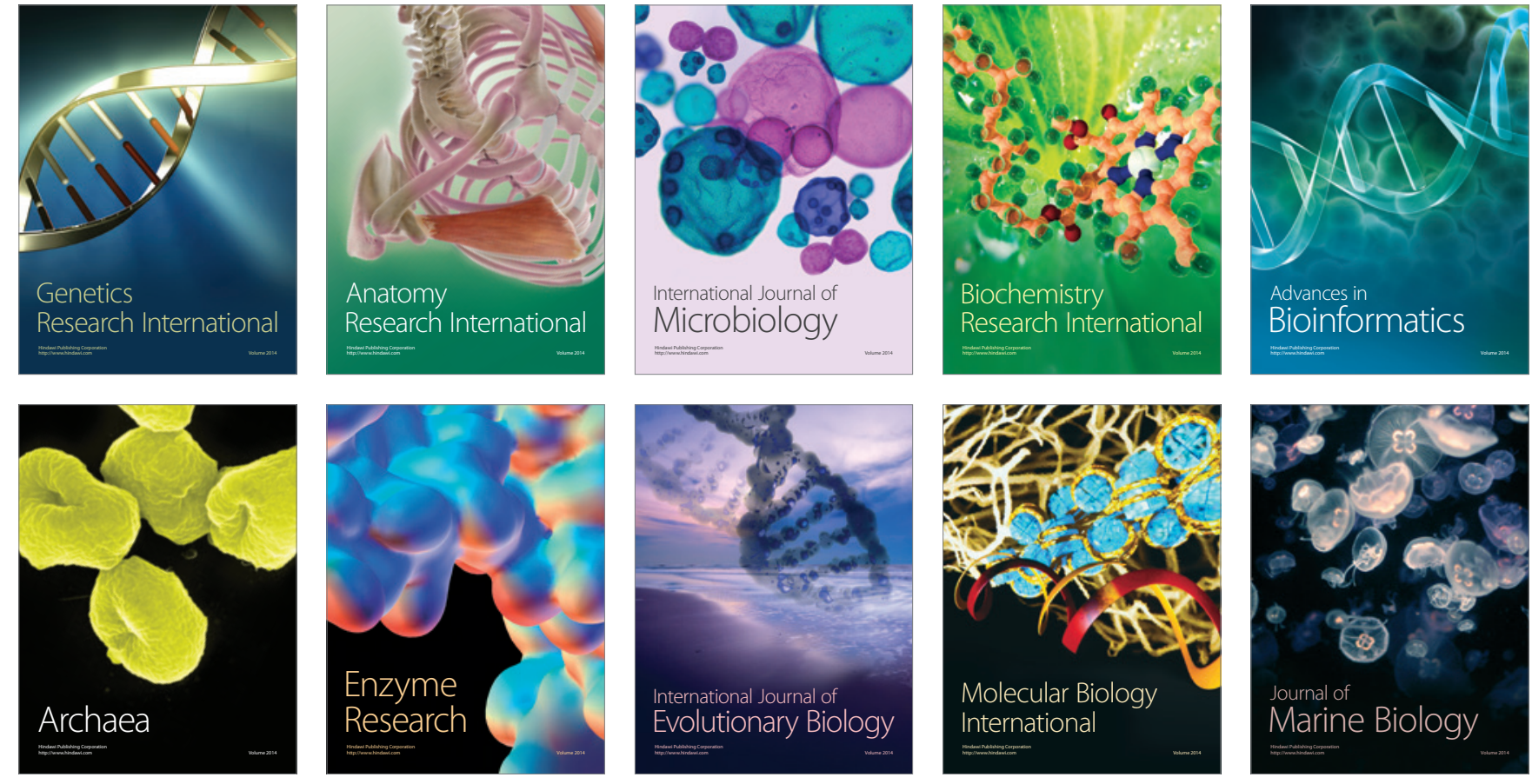